\title{
First language transfer and long-term structural priming in comprehension
}

\author{
Sanjo Nitschke
}

The University of Manchester, Manchester, UK

\section{Evan Kidd}

The University of Manchester, Manchester, UK and La Trobe University, Melbourne, Australia

\section{Ludovica Serratrice}

The University of Manchester, Manchester, UK

\begin{abstract}
The present study investigated L1 transfer effects in L2 sentence processing and syntactic priming through comprehension in speakers of German and Italian. L1 and L2 speakers of both languages participated in a syntactic priming experiment that aimed to shift their preferred interpretation of ambiguous relative clause constructions. The results suggested that L1 transfer affects L2 processing but not the strength of structural priming, and therefore does not hinder the acquisition of L2 parsing strategies. We also report evidence that structural priming through comprehension can persist in L1 and L2 speakers over an experimental phase without further exposure to primes. Finally, we observed that priming can occur for what are essentially novel form-meaning pairings for L2 learners, suggesting that adult learners can rapidly associate existing forms with new meanings.
\end{abstract}

Keywords: Priming; Comprehension; L1 transfer; German; Italian.

Correspondence should be addressed to Sanjo Nitschke, School of Psychological Sciences, The University of Manchester, Oxford Road, Manchester M13 9PL, UK. E-mail: sanjo.nitschke@postgrad.manchester.ac.uk

We thank two anonymous reviewers for the valuable feedback on an earlier draft of this paper.

C 2009 Psychology Press, an imprint of the Taylor \& Francis Group, an Informa business http://www.psypress.com/lcp

DOI: $10.1080 / 01690960902872793$ 


\section{INTRODUCTION}

First language syntactic transfer (L1 transfer) occurs when speakers use processing strategies from their L1 in their second language (L2). The occurrence of L1 transfer is disputed, and is either thought to strongly influence second language acquisition (SLA) and therefore be an essential component in models of the second language learning process (MacWhinney, 2004), or is regarded as irrelevant or even a hindrance to SLA (Clahsen \& Felser, 2006).

Evidence for syntactic L1 transfer was found in a series of studies carried out within the framework of the Competition Model (Bates \& MacWhinney, 1982). These studies aimed to identify the cues that participants use when identifying the subject of a sentence. Kilborn and Cooreman (1987) found indications for a partial deployment of L1 cue preferences in L2 subject identification tasks for L2 English L1 Dutch speakers. Gass (1987) reported carry-over effects from L1 Italian to L2 English but not from L1 English to L2 Italian. McDonald (1987) asked L1 and L2 speakers of Dutch and English to name the recipient in dative constructions or the subject of transitive sentences and found indications that L2 speakers initially adopt cue weights carried over from the L1, but gradually shift to L2 strategies with prolonged L2 exposure. Apart from Competition Model studies, other indications for effects of transfer that decrease as L2 exposure time increases can be found for relative clause attachments in Dussias (2003) and for German subject and object relative clauses in Hopp (2006). Further L1 transfer was reported by Frenck-Mestre and Pynte (1997) where French/ English speakers showed signs of hesitation while reading unambiguous L2 sentences that would have been ambiguous in their L1, suggesting L1 transfer. Flynn (1989) and Flynn and Espinal (1985) reported L1 transfer for subordinate clause embedding. Cross-linguistic structural priming studies, where the processing of a sentence in the L1 affects the production of a sentence in the L2 (Desmet \& Declercq, 2006; Hartsuiker, Pickering, \& Veltkamp, 2004; Salamoura \& Williams, 2007; Schoonbaert, Hartsuiker, \& Pickering, 2007) can also be interpreted as instances of L1 transfer. For further review on L1 transfer see Fernández (2003).

Even though a number of studies from different laboratories have found transfer effects, a few studies have reported null results. Felser, Roberts, Marinis, and Gross (2003) carried out a grammaticality judgement and a self-paced reading task with L2 English speakers who were native speakers of German or Greek. The structures of interest were ambiguous relative clause (RC) attachments, such as The dean liked the secretary of the professor who was reading a letter, where the $\mathrm{RC}$ who was reading a letter can be attached either to the secretary (NP1) or to the professor (NP2). Felser et al. reported on earlier studies that have shown German and Greek L1 speakers to prefer 
NP1 attachment, so their prediction was that, were transfer to occur, their participants would also display this preference in English, whereas L1 English speakers generally show a preference for NP2 attachment. The L2 speakers, however, showed no preference for NP1 or NP2 attachment, leading Felser et al. (2003) to argue against the presence of L1 transfer in L2 processing.

Data from Hernandez, Bates, and Avila (1994) suggest that highly advanced L2 speakers amalgamate strategies from both languages, which could explain the lack of clear preferences in the L2 learners in Felser et al. (2003). Papadopoulou and Clahsen (2003) aimed to address this question by testing L2 speakers of Greek with L1 Spanish, German, or Russian, who were reported in earlier studies to prefer NP1 attachments in their L1. Papadopoulou and Clahsen reported mixed L2 patterns and no clear NP1 preference, taking this as evidence against L1 transfer. However, as also pointed out by Miyao and Omaki (2006), Papadopoulou and Clahsen collapsed the data from the three L2 groups because no interaction could be found between L2 group and antecedent or attachment type. Thus, no analysis was conducted to compare the L1s with single L2 groups where meaningful effects of $\mathrm{L} 1$ transfer could potentially have been revealed. Given the small group sizes in their sample (as few as ten participants) it is also likely that the study lacked sufficient statistical power to detect mean group differences. Apart from this methodological issue, there are reports about different attachment preferences found even in native speakers (see Cuetos, Mitchell, \& Corley, 1996; Gilboy, Sopena, Clifton, \& Frazier, 1995; Scheepers, 2003; Miyao \& Omaki, 2006). If RC-attachment preferences vary within L1 speakers of single languages it is unlikely that this phenomenon lends itself well to testing for L1 transfer.

The current study investigated the possibility that preferences in ambiguity resolution are influenced by first language patterns, and whether such an influence would affect structural priming; that is, whether priming in L2 learners is influenced by a speaker's L1 knowledge. We also addressed the time course of structural priming and the persistence of the priming effect in L1 and L2 speakers. In the following we review the literature on structural priming; we focus on the persistence of the priming effect and in particular on priming in comprehension.

\section{Structural priming}

Structural priming refers to the observation that speakers tend to persist in using recently processed syntactic structures (Bock, 1986; Pickering \& Branigan, 1998). For instance, one is more likely to produce a passive sentence like The dog was chased by the cat after hearing a passive such as The telephone was answered by the secretary than after hearing the active 
equivalent The secretary answered the telephone. Structural priming has been successfully observed in L1 adult speakers (Bock, 1986), in young children (Savage, Lieven, Theakston, \& Tomasello, 2003) and in L2 learners within and across languages (Bernolet, Hartsuiker, \& Pickering, 2007; Salamoura \& Williams, 2006, 2007; Schoonbaert et al., 2007). For a more comprehensive review see Pickering and Ferreira (2008).

Most studies on structural priming have focused on production; however, the effect has also been demonstrated in comprehension. For instance, in a picture selection task Branigan, Pickering, and McLean (2005) successfully primed different interpretations of sentences containing ambiguous prepositional phrase attachments (e.g., The policeman saw the thief with the binoculars), provided the verb was repeated from prime to target. In an eye-tracking study, Arai, van Gompel, and Scheepers (2007) also found effects of priming in comprehension of English DO/PO constructions, but only when the verb overlapped. Additionally, Traxler and Tooley (2008) report priming in comprehension with overlapping verbs even though the predictive value of the verb was diluted by fillers containing the same verb. Verb general effects were shown by Scheepers and Crocker (2004) in an eyetracking study where L1 Germans' interpretations of NVN sentences with temporary subject-object ambiguity were affected by a directly preceding prime across modalities from reading to listening. Fewer studies suggest that priming in comprehension might be long-lasting. In an act-out task Thothathiri and Snedeker (2008) found priming in comprehension without open class lexical overlap in English double object and prepositional object sentences. The effect was also observed when the prime and target were interrupted by a generic, repeated filler ('It's my turn. Are you ready?'). Work by Kaschak and Glenberg (2004) demonstrated that reading times shortened with multiple repetitions of a new structure, and Luka and Barsalou (2005) found perceptions of grammaticality to increase with repeated exposure. Such effects of multiple exposures provide stronger evidence for long-lasting priming in comprehension.

The majority of studies investigating whether structural priming can be long lasting used a paradigm that primed for competing structures in an alternating fashion (e.g., Branigan, Pickering, Stewart, \& McLean, 2000; Bock \& Griffin, 2000; Bock, Dell, Chang, \& Onishi, 2007; Hartsuiker, Bernolet, Schoonbaert, Speybroeck, \& Vanderelst, 2008). For example, a typical experiment might use double object (DO, e.g., Romy gave Andreas a pen) and prepositional object (PO, e.g., Romy gave a pen to Andreas) dative primes in a within-subjects design. Though alternating designs could elicit long-term effects of priming there was also evidence for rapid decay (Branigan, Pickering, \& Cleland, 1999). It is possible that using competing structures may reduce long-term priming effects, since the use of one structure may inhibit the other. In contrast, solely priming the target 
structure may enhance persistence and strength of the effect (see Hartsuiker \& Westenberg, 2000; Kaschak, 2007; Kaschak, Loney, \& Borreggine, 2006; Thothathiri \& Snedeker 2008), and provide an opportunity to investigate the development of the priming effect over time.

\section{The present study}

The present study investigated L1 transfer and syntactic priming through comprehension in L1 and L2 speakers. We tested comprehension of German and Italian RC structures that are structurally ambiguous between subject and object interpretations, but which correspond to unambiguous subject and object RCs in English. Consider sentences (1) and (2):

(1) German: Hier ist die Frau, die das Mädchen küsst

(2) Italian: Ecco la donna che bacia la ragazza

'Here is the $\operatorname{woman}_{[\mathrm{Subj} / \mathrm{Obj}]}$ that kisses the $\operatorname{girl} \mathrm{Obbj/Subj]}$ '

The German and the Italian examples are syntactically identical to their English counterparts. While in English the subject role can only be taken by the second NP in (1) and by the first NP in (2), German and Italian allow subject role assignment to either NP. Despite the ambiguity, German and Italian natives prefer to assign the subject role to the NP1, 'woman' in (1) and (2) (Carminati, Guasti, Schadee, \& Luzzati, 2006; Hopp, 2006). Thus, the preferred Italian interpretation of the NVN RC construction as SVO coincides with the only acceptable role assignment in its English NVN RC equivalent, while the German preference for SOV contradicts the only accepted role assignment of its English NNV RC counterpart. For this reason these ambiguous structures in German and Italian provide an opportunity to determine whether there is cross-linguistic transfer from English.

We tested L1 speakers of German and Italian and L2 speakers of these languages who were L1 English speakers on a syntactic priming task that aimed to prime OR of these ambiguous German and Italian structures through comprehension. The task had three phases that were designed to test for the presence of L1 transfer and long-term persistence of priming. We had the following predictions for the occurrence of L1 transfer. First, since English only allows NNV RCs to be interpreted as OSV, and because the ambiguous NNV RCs in German are preferably interpreted by L1s as SOV, we expected L2 German participants to display a higher preference for object reading (OR) decisions than native Germans if there was L1 transfer. Second, because English only allows a SVO role assignment for NVN RCs and L1 Italians prefer a SVO role assignment, we expected few if any OR and 
high proportions of subject readings (SR) in both the L1 and L2 Italians. Additionally, we tested whether L1 transfer would affect the strength of structural priming of OR interpretations leading to enhanced effects in the L2 Germans while limiting the effect in the L2 Italians. Finally, we analysed the development and the persistence of the priming effect in all of the speaker groups.

\section{METHOD}

\section{Participants}

Ninety-six $(\mathrm{N}=96)$ adult speakers were recruited from the student population at The University of Manchester, UK. There were four participant groups: native speakers of German (L1 Germans), native speakers of Italian (L1 Italians), native English speakers who were L2 speakers of German (L2 Germans) and native English speakers who were L2 speakers of Italian (L2 Italians). There were 24 participants in each group.

The L1 Germans and Italians studied at universities in their home countries and had been in the UK as exchange students for less than six months at the time of testing. The L1 Germans (11 male, 13 female) had a mean age of 23 years (min: 20, max: 26) and reported to have not started learning any second language before 8 years of age. Two L1 Germans were from Austria, the other 22 were from Germany. The L1 Italians ( 7 male, 17 female) all came from Italy, were on average 23 years old (min: 18, max: 30), and had not learned any second language before the age of 6 .

The L2 learners were all native English speakers, from the UK $(n=47)$ and the USA $(\mathrm{n}=1)$ and had also not learned any second language before the age of 6. All had studied German or Italian for at least 2 years at university or had obtained A-grade A-levels in German or Italian at high school. ${ }^{1}$ The L2 German group included 8 male and 16 female participants. The mean age was 21 years (range: $18-23$ years) and on average they had studied German for 9 years (range: 2-12 years). During their studies, 19 L2 Germans had been studying or working in Germany or Switzerland for an average of 5 months (range: $0.5-11$ months), one went to school in Germany for 5 years, and four students had not been to Germany for longer than 2 weeks at a time.

Of the L2 Italian participants, 9 were male and 15 female. Their mean age was 21 years (min: 19, max: 24), and they had been studying Italian for an

\footnotetext{
${ }^{1}$ In the UK an A-level is the final year of secondary education (i.e., high school). An A-grade indicates a 'proficient user' (C1), according to the Common European Framework Global Assessment Scale (see: http://www.coe.int/T/DG4/Portfolio/?L=E\&M=/main_pages/ levels.html).
} 
average of 5 years (range: 3-9 years). Twenty-one of the L2 Italians had studied or worked in Italy for an average of 8 months (range: 2-12 months). One student went to university in Italy for 26 months and two students had not been to Italy for longer than 2 weeks at a time.

\section{Materials}

The experiment was a picture selection task that included 166 sentences, each followed by two pictures. The experimental sentences were 64 ambiguous relative clauses (see Appendix) and 102 fillers, amongst which were 32 structurally ambiguous prepositional phrase (PP) attachment sentences (e.g., The clown hits the doctor with the hammer). The PP-attachment sentences served to divert the attention of any participants who recognised the RC ambiguity away from the aim of the experiment. The remaining 70 fillers were non-ambiguous active (e.g., The man is reading a book to the boy), passive (The boy is scared by the ghost) and intransitive sentences (e.g., The sportsman is running). Half of the PP-attachment sentences were disambiguated by the accompanying pictures; only one picture matched the possible reading because the other contained an incorrect object not mentioned in the sentence. Together with the 70 unambiguous fillers these disambiguated PPattachment sentences also served to verify that the L2 speakers were competent in their second language.

The experimental RCs contained 16 different human characters and 16 different verbs. In order to avoid disambiguation by case marking in German, the selected characters were either neuter or female in their German translation, where the case marking on the relative pronoun is ambiguous between subject- and object-extraction. In Italian the gender does not influence syntactic ambiguity; however, to use the same 128 pictures for both languages the characters of the Italian version were all female, apart from one: ragazzino (male, 'boy', translated as the neuter noun Kind 'child' in the German experiment).

\section{Procedure}

The experiment was a picture selection task and was presented using the E-prime software (MacWhinney, James, Schunn, Li, \& Schneider, 2001). Participants were seated at a computer and received aural and written onscreen instructions in their L1. They were not informed about the aim of the study but were told that it investigated language processing in second language acquisition and that it was not a memory test and they would not have to memorise any of the sentences or corresponding scenes. They were told that single sentences would be displayed on the screen, which would be followed by two pictures. They were required to select the picture that matched the sentence by pressing the relevant key on a button box. The 
presentation of the sentences and pictures was self-paced. Participants were, however, encouraged to respond promptly in order to discourage metalinguistic processing. The test commenced with a training session of six additional unambiguous filler sentences.

The presentation of the test items was divided into three continuous stages: a baseline phase containing 16 ambiguous RCs, a prime phase with 16 prime-target RC pairs, and a post test phase containing 16 ambiguous RCs. The baseline phase was created to (i) verify the assumption that un-primed L1 German and Italian participants preferred the subject reading (SR) of the RCs over the object reading (OR), and to (ii) measure L1 transfer in the L2 participant groups. Therefore, in the baseline phase the pictures following each relative clause provided both possible meanings, the SR and the OR. The prime phase aimed to change the participants' preferences from the SR to the OR. Here, the first sentence of each pair, the prime, allowed only the OR, whereas the second sentence, the target, was left ambiguous. The post test phase tested the sustainability of the expected priming effect for ORs. Therefore, as in the baseline, both readings were provided to the participant without any further priming. No item occurred more than once throughout the experiment and the items were presented randomly within two different lists for each of the four participant groups.

A prime-target pair from the prime phase of the experiment is reproduced in Figure 1. First, the German or Italian prime sentence ('Here is the photographer that the ballerina scares') was displayed. Next, after pushing a button the sentence disappeared and two pictures replaced it. One of the pictures showed the ballerina scaring the photographer (the OR), and the other picture was unrelated, showing the ballerina calling for the photographer. Second, the target item contained a new sentence with the same verb followed by two pictures matching both the SR and the OR. The logic behind the design was that, since only the OR was available during the prime trial, the participants should have been more likely to select an OR during the target trial, even though both the SR and OR would be available.

The positions of the picture pairs (left or right) were counterbalanced within all versions of the experiment (left-left, left-right, right-right, rightleft) and occurred in random order. Following the completion of the priming experiment the participants were thanked, debriefed and compensated $£ 5$ for their time.

\section{RESULTS}

All participants completed the whole experiment. At first we investigated the ratios of correct filler responses to assess linguistic understanding and attention during the experiment. All four speaker groups responded correctly 
PRIME TRIAL

GER: Hier ist die Fotografin, die die Ballerina erschreckt.

'Here is the photographer ${ }_{[S u b / O b j]}$ that the ballerina $a_{[0 b j / S u b]}$ scares'

ITA: Ecco la fotografa che spaventa la ballerina.

'Here is the photographer ${ }_{[S u b / O b j]}$ that scares the ballerina $a_{[O b j / S u b]}$


TARGET TRIAL

GER: Hier ist die Großmutter, die die Malerin erschreckt.

'Here is the grandmother [Sub/Obj] $_{\text {that }}$ the painter [Obj/Sub] $_{\text {Scares' }}$

ITA: Ecco la nonna che spaventa la pittrice.

'Here is the grandmother $r_{[S u b / O b j]}$ that scares the painter $r_{[O b j / S u b]}$ '
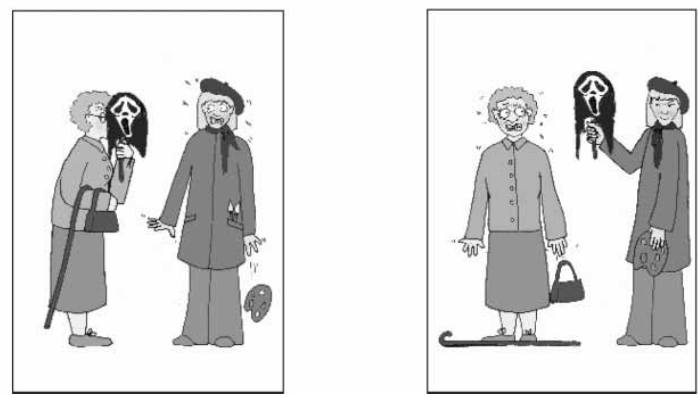

Figure 1. Example for a prime and target item of the experimental condition.

to at least $93 \%$ of the filler items, including the disambiguated PP attachment items. The German L1 and L2 speakers correctly responded to an average of $98 \%$ of the fillers (min: $93 \%, \max 100 \%, M S E=.004$ ). The L1 Italian group responded correctly to $99 \%$; the L2 Italians to $98 \%$ (the range was identical in both groups: $\min : 95 \%$, $\max : 100 \%, M S E=0.003$ ). A univariate ANOVA revealed no difference in filler responses between the four speaker groups $(p>.05)$. We therefore assumed that the L2 participants had mastered their second language well enough to produce meaningful data. Overall, the participants responded correctly to $91 \%$ of the unambiguous prime trials; 
that is, they chose the OR reading of the prime $91 \%$ of the time when this was the only reading available to them. Therefore on a small percentage of occasions the participants chose the unrelated picture; however, since this number was relatively small, and the results do not change when we excluded these data, we chose to include those trials when participants chose the incorrect prime picture so as to increase the number of data points in our analyses of the priming data.

The data of the experimental items were analysed next. Proportions of ORs were calculated for each participant separately for the baseline, prime and post test phases by dividing the sum of the OR choices in the target items by the number of target items in each phase (i.e., 16). A summary of the data is shown in Figure 2.

The data in Figure 2 indicate an increase of ORs from the baseline to the prime phase for the German L1s and L2s, and the Italian L2s. For those three groups, the proportions of ORs are also higher in the post test than they were during the baseline phase. The proportion of ORs remained fairly stable from the prime phase to the post test phase in the German groups yet increased slightly in the L2 Italians. The proportions in the L1 Italians remained relatively unchanged throughout the experiment. The German groups made generally more OR choices than the Italians. L2 speakers selected more OR pictures overall than did the L1 speakers.

The proportions of OR readings were arcsine transformed $[\mathrm{Y}=$ $2 * \operatorname{arcsine}(\operatorname{sqrt}(\mathrm{p}))]$ according to Howell (1992) and all statistical analyses were run on the transformed and the untransformed data. There was no qualitative difference between the results of the analyses based on the transformed and untransformed data, so we report the results for the untransformed data only. ANOVAs were carried out by participants $\left(F_{1}\right)$ and

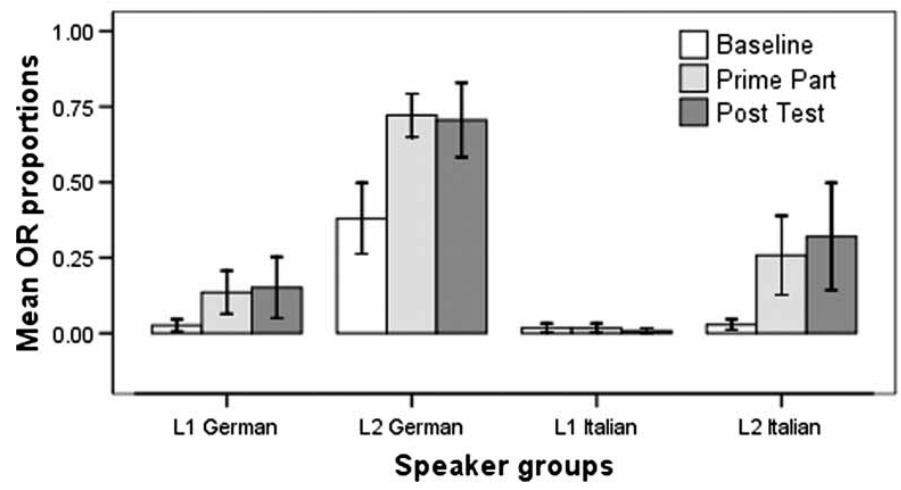

Figure 2. Development of object readings (OR) as a function of time over the three experimental phases. Error bars represent $95 \%$ confidence interval. 
by items $\left(F_{2}\right)$ and the more conservative $\min F^{\prime}$ was also calculated. If not further specified, the alpha level was $p<.05$.

At first an analysis was performed to compare only the baseline proportions of ORs of the four speaker groups. A univariate ANOVA using the baseline responses of the four speaker groups as the dependent measure showed a significant effect of speaker group, $F_{1}(3,92)=36.96, p<.001$, $M S E=.021, \eta^{2}=.547 ; F_{2}(3,92)=45.32, p<.001, M S E=.013$, partial $\eta^{2}=.84 ; \min F^{\prime}(3,118)=32.35, p<.001$. Pairwise comparisons with Bonferroni adjustment revealed that the responses did not differ between L1 Germans, L1 Italians, and L2 Italians (all $p s>.05$ ), but that the L2 Germans made more OR choices during the baseline phase than any of the other three speaker groups (all $p \mathrm{~s}<.001$ ). These results indicate a clear effect of L1 transfer in the predicted direction for the L2 Germans and L2 Italians during the baseline phase of the experiment.

Next, the data from all three phases of the experiment were analysed together. A 3 (time: baseline, prime, post test) $\times 2$ (language German versus Italian) $\times 2$ (nativeness: L1 versus L2) repeated measures ANOVA was conducted. There was a significant main effect of time, $F_{1}(1.5,139)=34.10$, $p<.001, \quad M S E=0.039$, partial $\eta^{2}=.27 ; \quad F_{2}(2,93)=146.32, \quad p<.001$, $M S E=0.009$, partial $\eta^{2}=.76 ; \min F^{\prime}(1.5,195)=27.65, p<.001$. Pairwise comparisons with Bonferroni adjustment for the by-participants statistics and Bonferroni post hoc tests for the by-items analysis revealed a significant overall increase of object reading proportions from the baseline phase to the prime phase, and from the baseline phase to the post test phase $(p s<.05)$. There was also a significant main effect for language, $F_{1}(1,92)=53.60$, $p<.001, \quad M S E=.08$, partial $\eta^{2}=.37 ; \quad F_{2}(1,93)=643.65, \quad p<.001$, $M S E=.009$, partial $\eta^{2}=.87 ; \min F^{\prime}(1,107)=49.48, p<.001$, indicating that the German-speaking participants made significantly more OR readings than did the Italian-speaking groups. Finally, there was a significant main effect of nativeness, $F_{1}(1,92)=105.16, p<.001, M S E=0.08$, partial $\eta^{2}=.53 ; \quad F_{2}(1,93)=1387.33, \quad p<.001, \quad M S E=0.008$, partial $\eta^{2}=.94 ;$ $\min F^{\prime}(1,106)=97.75, p<.001$, which revealed that L2 speakers chose more ORs than did the L1s. A significant time by nativeness interaction, $F_{1}(1.5,139)=15.92, p<.001, M S E=0.039$, partial $\eta^{2}=.15 ; F_{2}(2,93)=$ 77.96, $p<.001, M S E=0.008$, partial $\eta^{2}=.63 ; \min F^{\prime}(1.5,190)=13.22$, $p<.001$, indicated that the changes of OR proportions over time differed depending on whether participants were L1 or L2 speakers. Multiple Bonferroni comparisons showed that, for the L1s, only the increase of OR proportions from the baseline phase to the priming phase was significant $(p<.05)$. For the L2s, the increase from the baseline to the priming phase was significant $(p<.05)$, as was the increase from the baseline to the post test $(p<.05)$. 
Another interaction was found between language and nativeness, $F_{1}(1, \quad 92)=21.59, \quad p<.001, \quad M S E=0.08 \quad \eta^{2}=.19 ; \quad F_{2}(1, \quad 93)=259.42$, $p<.001, M S E=0.009$, partial $\eta^{2}=.74 ; \min F^{\prime}(1,107)=19.93, p<.001$, indicating that the number of ORs for each language depended on whether the participant was native. Specifically, the interaction is carried by the high number of ORs in the L2 German data $(M=0.602, S E M=0.038)$ in contrast to the other three speaker groups (L1 German: $M=0.104$, $S E M=0.026$; L1 Italian: $M=0.148, S E M=0.004$; L2 Italian: $M=0.202$, $S E M=0.048)$.

The time by language interaction was significant by items, $F_{2}(2,93)=$ 11.62, $p<.001, M S E=0.009$, partial $\eta^{2}=.20$, but not by subjects, $F_{1}(1.5,139.05)=2.74, p=.08, M S E=0.039 \eta^{2}=.29$. The three-way interaction of time by language by nativeness was not significant, $F_{1}<1$, $F_{2}(2,93)=2.33, p=.10, M S E=0.021 \eta^{2}=.05$. The rise of the OR proportion from the baseline phase to the post test phase was therefore similar for the L2 Italians and the L2 Germans and unaffected by L1 transfer.

To investigate the development of the prime effect over time, the target responses during the priming phase of the experiment were divided into four clusters, each comprising four items, as shown in Figure 3.

Figure 3 shows that there was little overall change in the number of ORs for the L1 Germans and that there were very few ORs in the L1 Italians. The L2 Germans showed a slight tendency to increase the OR proportions over time. In the L2 Italians the ORs increased from the first to the third cluster and remained stable during the fourth cluster. Polynomial contrasts of the clusters of the prime phase revealed no effect for the German groups and for the L1 Italians. For the L2 Italians, however, a linear trend was found by

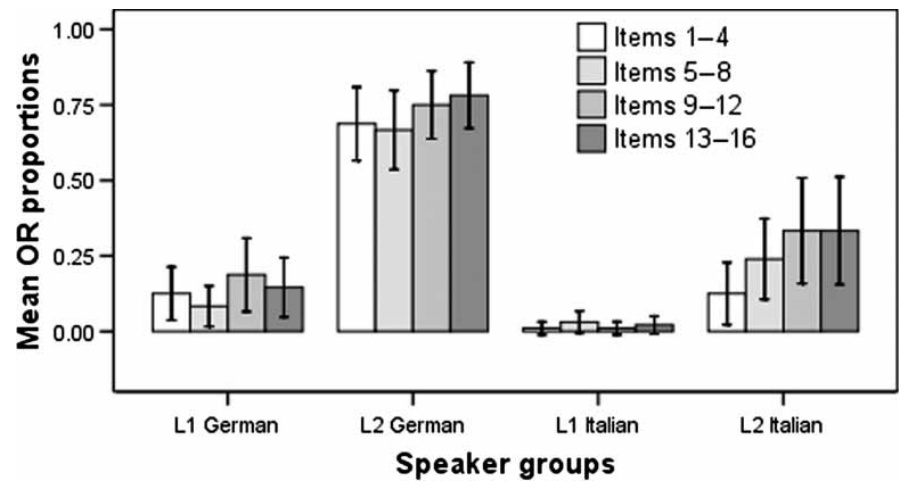

Figure 3. Development of object readings (OR) as a function of time within the prime phase. Error bars represent $95 \%$ confidence interval. 
subjects, $F(1,23)=7.24, p=.013, M S E=0.62$, partial $\eta^{2}=.24$, but not by items $(p=.09)$, indicating a proportional increase of OR responses over the priming phase of the experiment. No trend was found for any group during the baseline and post test phases of the experiment.

\section{DISCUSSION}

The present study showed clear evidence that L1 transfer occurs in L2 speakers but also revealed that it can be overridden by syntactic priming and therefore does not appear to inhibit learning of new structures. It was also found that priming in comprehension is long-lasting, can emerge gradually, and can be persistent in the L1 and L2. We also found that structural priming is stronger in L2 than in L1 speakers. We consider each of these issues in turn.

A strong effect of $\mathrm{L} 1$ transfer was evident in the baseline data, where, as predicted, the L2 German participants made significantly more OR choices than any of the three other groups. In English a NNV RC can only be interpreted as OSV, while in German this RC structure is ambiguous with a preference for SOV. Thus, L1 transfer should have resulted in a higher proportion of OSV readings in the L2 Germans than in the L1 Germans. This is what we found. It was also predicted that due to L1 transfer, the OR proportions of L1 and L2 Italians would converge on a low level because this reading is dispreferred in Italian NVN RCs and impossible for English NVN relatives. This hypothesis was also confirmed. Our findings therefore support previously reported instances of L1 transfer (e.g., Frenck-Mestre \& Pynte, 1997; Gass, 1987; Hopp, 2006; Kilborn \& Cooreman, 1987; McDonald, 1987). Furthermore, we found that L2 learners do not show L2-general patterns. The baseline data differed between the German and Italian learners but not between the native speaker groups. Consequently, non-nativeness alone cannot account for the results, and the suggestion that L1 and L2 speakers adopt qualitatively different parsing strategies (Felser, Roberts, Marinis, \& Gross, 2003; Papadopoulou \& Clahsen, 2003) was not supported in the baseline phase.

However, while we found an effect of L1 transfer in the baseline data, priming was unaffected by the $\mathrm{L} 1$ as there was no three-way time by language by nativeness interaction, indicating similarly strong effects of OR priming for both L2 groups. An effect of transfer on priming would have suggested a stronger effect in the L2 Germans than in the L2 Italians. The only difference was that for the L2 Germans the effect was immediate whereas for the L2 Italians the effect numerically increased over the course of the experiment. Therefore, although L1 transfer may be guiding SLA, as the L2 baseline data suggest, the data also showed that priming is possible in 
circumstances where the prime is inconsistent with preferences carried over by L1 transfer, as was the case for the L2 Italians. In this respect there is no reason to regard L1 transfer as 'a barrier to acquiring full native-like competence and/or fluency in the L2' (Clahsen \& Felser, 2006, p. 5), since what are effectively 'old' surface structures in the L1 can be re-used in the L2 to denote a different meaning. Apparently the language learning system is still fairly flexible even in adulthood (see Boyd, Gottschalk, \& Goldberg, in press; Goldberg, Casenhiser, \& Sethuraman, 2004).

The lack of evidence for L1 transfer in some of the previous studies can potentially be attributed to the lack of statistical power and the nature of the materials used, such as RC attachment ambiguities. Although it is often claimed that speakers of a given language will have a preference for either low or high attachment, there seems to be a considerable degree of variability (see Cuetos et al., 1996; Gilboy, Sopena, Clifton, \& Frazier, 1995; Miyao \& Omaki, 2006; Scheepers, 2003).

Structural priming was clearly evident in the L1 and L2 Germans and in the L2 Italian group. No effect was found for the L1 Italians, who displayed a constantly low level of ORs throughout the experiment. One question therefore concerns why the L1 Italians could not be primed. In Italian the OR of a NVN RC is extremely rare and dispreferred (see Carminati et al., 2006). The L2 Italians in the present study were all native English speakers and English does not permit an OR of NVN RCs. Thus, the OR reading of the NVN RC-structure was probably not known to the L2 Italians either. However, because the L2 speakers only learned Italian during adulthood, their experience with the language is limited and parsing strategies are less entrenched than those of L1 speakers. In line with experience-based learning accounts of syntactic processing (Chang, Dell, \& Bock, 2006; Mitchell, 1994), reduced exposure is equivalent to weaker representations, which may render L2 speakers more susceptible to priming than L1 adult speakers. We therefore assume that the weak linear trend found in the L2 Italians (Figure 3) reflects a learning process. We make no claims about the nature of what has been learned; that is, whether or not the L2 Italians were annotating an existing N-RelPro-V-N structure with different semantics or whether they were learning a new and separately represented form-meaning mapping. This result is consistent with past research that has shown multiple exposures to modify participants' processing and acceptability judgements of novel or moderately grammatical structures (Kaschak \& Glenberg, 2004; Luka \& Barsalou, 2005). Our results suggest that the strength of a participant's existing grammatical representation, as measured by the amount of exposure they have had to the language, drives this effect (see also Cuetos et al., 1996; Chang, Dell, Bock, \& Griffin, 2000; for specific examples concerning RCs see Kidd, Brandt, Lieven, \& Tomasello, 2007; Wells, Christiansen, Race, Acheson, \& MacDonald 2009). At the same time, we rule out 
experiment-specific strategies. For instance, if the correct choice of the ORs in the prime sentences were a mere strategy to cope with the unexpected syntactic role mapping then participants should not have selected the ORs in the targets of the prime phase or indeed the post test phase of the experiment.

In the successfully primed speaker groups the increased proportions of ORs persisted throughout the post test phase, in which no further primes were administered. This supports the first indication of long-lasting priming in comprehension reported by Thothathiri and Snedeker (2008) for L1 speakers, and provides the first evidence for long-lasting priming in comprehension in L2 speakers. Work by Hartsuiker et al. (2008) suggests that structural priming does not persist if it depends on lexical overlap. In our study we had verb overlap from prime to target and the priming effect still turned out to be long lasting. It is possible that the effect over the post test phase may have been reinforced because participants still came into contact with the target structure. That is, when participants chose an OR during the post test phase they may have effectively 'self-primed' themselves (see Savage, Lieven, Theakston, \& Tomasello, 2006). However, even if this were the case the effect still had to persist over sequences of up to four intervening filler items within the post test, and therefore must still have been long lasting. It is therefore likely that the effect became long-lasting because we only primed for the OR instead of alternating between competing SR and OR, allowing the effect to accumulate (see Hartsuiker \& Westenberg, 2000; Kaschak, 2007; Kaschak et al., 2006). If this was the case then accumulation of priming should occur even without lexical overlap between primes and targets. Our future work addresses this issue.

\section{GENERAL CONCLUSION}

The present study found strong evidence that L1 language processing strategies influence L2 processing but that these L1 transfer effects can be overridden by exposure to competing structural patterns. L1 transfer may therefore be initially misleading for L2 learners when L1 and L2 differ in certain respects but it does not appear to seriously hinder SLA. The present data also provide the first demonstration of long-lasting priming in comprehension in L1 and L2 speakers over a number of different and unrelated filler items. We also found indications that the priming effect develops over time and is stronger in L2 than in the more experienced L1 speakers, and that priming in comprehension can be long-lasting if one target structure is consistently primed. It was also shown that structural priming is 
not limited to familiar parsing routines, but can also be successfully observed if the prime is novel in nature, indicating instances of learning.

Manuscript received October 2008

Revised manuscript received March 2009

First published online May 2009

\section{REFERENCES}

Arai, M., van Gompel, R. P. G., \& Scheepers, C. (2007). Priming ditransitive structures in comprehension. Cognitive Psychology, 54(3), 218-250.

Bates, E., \& MacWhinney, B. (1982). Functionalist approaches to grammar. In E. Wanner \& L. Gleitman (Eds.), Language acquisition: The state of the art (pp. 173-218). New York: Cambridge University Press.

Bernolet, S., Hartsuiker, R. J., \& Pickering, M. J. (2007). Shared syntactic representations in bilinguals: Evidence for the role of word-order repetition. Journal of Experimental Psychology: Learning, Memory, and Cognition, 33(5), 931-949.

Bock, J. K. (1986). Syntactic persistence in language production. Cognitive Psychology, 18(3), 355-387.

Bock, K., Dell, G. S., Chang, F., \& Onishi, K. H. (2007). Persistent structural priming from language comprehension to language production. Cognition, 104(3), 437-458.

Bock, K., \& Griffin, Z. M. (2000). The persistence of structural priming: Transient activation or implicit learning? Journal of Experimental Psychology: General, 129(2), 177-192.

Boyd, J. K., Gottschalk, E. A., \& Goldberg, A. E. (in press). Linking rule acquisition to novel phrase constructions. Language Learning.

Branigan, H. P., Pickering, M. J., \& Cleland, A. A. (1999). Syntactic priming in written production: evidence for rapid decay. Psychonomic Bulletin and Review, 6(4), 635-640.

Branigan, H. P., Pickering, M. J., \& McLean, J. F. (2005). Priming prepositional-phrase attachment during comprehension. Journal of Experimental Psychology: Learning, Memory, and Cognition, 31(3), 468-481.

Branigan, H. P., Pickering, M. J., Stewart, A. J., \& McLean, J. F. (2000). Syntactic priming in spoken production: linguistic and temporal interference. Memory and Cognition, 28(8), 1297-1302.

Carminati, S., Guasti, M. T., Schadee, H., \& Luzzatti, C. (2006). Subject and object relative clauses in Italian: Normal subjects and an agrammatic patient. Brain and Language, 99(1-2), 153-154.

Chang, F., Dell, G. S., \& Bock, K. (2006). Becoming syntactic. Psychological Review, 113(2), 234-272.

Chang, F., Dell, G. S., Bock, K., \& Griffin, Z. M. (2000). Structural priming as implicit learning: A comparison of models of sentence production. Journal of Psycholinguistic Research, 29(2), 217-229.

Clahsen, H., \& Felser, C. (2006). Grammatical processing in language learners. Applied Psycholinguistics, 27(1), 3-42.

Cuetos, F., Mitchell, D. C., \& Corley, M. M. B. (1996). Parsing in different languages. In M. Carreiras, J. E. García-Albea, \& N. Sebastián-Gallés (Eds.), Language processing in Spanish. Mahwah, NJ: Lawrence Erlbaum Associates.

Desmet, T., \& Declercq, M. (2006). Cross-linguistic priming of syntactic hierarchical configuration information. Journal of Memory and Language, 54(4), 610-632. 
Dussias, P. E. (2003). Syntactic ambiguity resolution in L2 learners. Studies in Second Language Acquisition, 25(04), 529-557.

Felser, C., Roberts, L., Marinis, T., \& Gross, R. (2003). The processing of ambiguous sentences by first and second language learners of English. Applied Psycholinguistics, 24(03), 453-489.

Fernández, E. M. (2003). Bilingual sentence processing: Relative clause attachment in English and Spanish. Amsterdam: John Benjamins.

Flynn, S. (1989). Spanish, Japanese and Chinese speakers' acquisition of English relative clauses: new evidence for the head direction parameter. In K. Hyltenstam \& L. K. Obler (Eds.), Bilingualism across the lifespan. Aspects of acquisition, maturity, and loss. Cambridge, UK: Cambridge University Press.

Flynn, S., \& Espinal, I. (1985). Head/initial head/final parameter in adult Chinese L2 acquisition of English. Second Language Research, 1(2), 93-117.

Frenck-Mestre, C., \& Pynte, J. (1997). Syntactic ambiguity resolution while reading in second and native languages. Quarterly Journal of Experimental Psychology, 50A(1), 119-148.

Gass, S. M. (1987). The resolution of conflicts among competing systems: A bidirectional perspective. Applied Psycholinguistics, 8, 329-350.

Gilboy, E., Sopena, J.-M., Clifton, C., \& Frazier, L. (1995). Argument structure and association preferences in Spanish and English complex NPs. Cognition, 54(2), 131-167.

Goldberg, A. E., Casenhiser, D. M., \& Sethuraman, N. (2004). Learning argument structure generalizations. Cognitive Linguistics, 15(3), 289.

Hartsuiker, R. J., Bernolet, S., Schoonbaert, S., Speybroeck, S., \& Vanderelst, D. (2008). Syntactic priming persists while the lexical boost decays: Evidence from written and spoken dialogue. Journal of Memory and Language, 58(2), 214-238.

Hartsuiker, R. J., Pickering, M. J., \& Veltkamp, E. (2004). Is syntax separate or shared between languages? Cross-linguistic syntactic priming in Spanish-English bilinguals. Psychological Science, 15(6), 409-414.

Hartsuiker, R. J., \& Westenberg, C. (2000). Word order priming in written and spoken sentence production. Cognition, 75(2), B27-B39.

Hernandez, A. E., Bates, E. A., \& Avila, L. X. (1994). On-line sentence interpretation in SpanishEnglish bilinguals: What does it mean to be "in between"? Applied Psycholinguistics, 15, 417446.

Hopp, H. (2006). Syntactic features and reanalysis in near-native processing. Second Language Research, 22(3), 369-397.

Howell, D. C. (1992). Statistical methods of psychology (3rd ed.). Belmont, CA: Duxbury Press.

Kaschak, M. P. (2007). Long-term structural priming affects subsequent patterns of language production. Memory and Cognition, 35(5), 925-937.

Kaschak, M. P., \& Glenberg, A. M. (2004). This construction needs learned. Journal of Experimental Psychology: General, 133(3), 450-467.

Kaschak, M. P., Loney, R. A., \& Borreggine, K. L. (2006). Recent experience affects the strength of structural priming. Cognition, 99(3), B73-B82.

Kidd, E., Brandt, S., Lieven, E., \& Tomasello, M. (2007). Object relatives made easy: A crosslinguistic comparison of the constraints influencing young children's processing of relative clause. Language and Cognitive Processes, 22, 860-897.

Kilborn, K., \& Cooreman, A. (1987). Sentence interpretation strategies in adult Dutch-English bilinguals. Applied Psycholinguistics, 8, 415-431.

Luka, B. J., \& Barsalou, L. W. (2005). Structural facilitation: Mere exposure effects for grammatical acceptability as evidence for syntactic priming in comprehension. Journal of Memory and Language, 52(3), 436-459.

MacWhinney, B. (2004). A unified model of language acquisition. In J. F. Kroll \& A. D. Groot (Eds.), Handbook of bilingualism: Psycholinguistic approaches. New York: Oxford University Press. 
MacWhinney, B., James, J. S., Schunn, C., Li, P., \& Schneider, W. (2001). STEP - A system for teaching experimental psychology using E-Prime. Behavior Research Methods, Instruments and Computers, 33(2), 287-296.

McDonald, J. L. (1987). Sentence interpretation in bilingual speakers of English and Dutch. Applied Psycholinguistics, 8, 379-413.

Mitchell, D. C. (1994). Sentence parsing. In M. A. Gernsbacher (Ed.), Handbook of psycholinguistics (pp. 375-409). San Diego, CA: Academic Press.

Miyao, M., \& Omaki, A. (2006). No ambiguity about it: Korean learners of Japanese have a clear attachment preference. In D. Bamman \& T. Magnitskaia (Eds.), Proceedings of the 30th Annual Boston University Conference on Language Development Supplement. Somerville, MA: Cascadilla Press.

Papadopoulou, D., \& Clahsen, H. (2003). Parsing strategies in L1 and L2 sentence processing: A study of relative clause attachment in Greek. Studies in Second Language Acquisition, 25(4), 501-528.

Pickering, M. J., \& Branigan, H. P. (1998). The representation of verbs: evidence from syntactic priming in language production. Journal of Memory and Language, 39(4), 633-651.

Pickering, M. J., \& Ferreira, V. S. (2008). Structural priming: A critical review. Psychological Bulletin, 134(3), 427-459.

Salamoura, A., \& Williams, J. N. (2006). Lexical activation of cross-language syntactic priming. Bilingualism: Language and Cognition, 9(3), 299-307.

Salamoura, A., \& Williams, J. N. (2007). Processing verb argument structure across languages: Evidence for shared representations in the bilingual lexicon. Applied Psycholinguistics, 28(4), $627-660$.

Savage, C., Lieven, E., Theakston, A., \& Tomasello, M. (2003). Testing the abstractness of children's linguistic representations: lexical and structural priming of syntactic constructions in young children. Developmental Science, 6(5), 557-567.

Savage, C., Lieven, E., Theakston, A., \& Tomasello, M. (2006). Structural priming as implicit learning in language acquisition: The persistence of lexical and structural priming in 4-yearolds. Language Learning and Development, 2(1), 27-49.

Scheepers, C. (2003). Syntactic priming of relative clause attachments: persistence of structural configuration in sentence production. Cognition, 89(3), 179-205.

Scheepers, C., \& Crocker, M. W. (2004). Constituent order priming from reading to listening: A visual-world study. In M. Carreiras \& C. Clifton Jr (Eds.), The on-line study of sentence comprehension: Eye-tracking, ERP and beyond (pp. 167-185). New York: Psychology Press.

Schoonbaert, S., Hartsuiker, R. J., \& Pickering, M. J. (2007). The representation of lexical and syntactic information in bilinguals: Evidence from syntactic priming. Journal of Memory and Language, 56(2), 153-171.

Thothathiri, M., \& Snedeker, J. (2008). Give and take: Syntactic priming during spoken language comprehension. Cognition, 51(1), 51-56.

Traxler, M., \& Tooley, K. M. (2008). Priming in sentence comprehension: Strategic or syntactic? Language and Cognitive Processes, 23, 609-645.

Wells, J. B., Christiansen, M. H., Race, D. S., Acheson, D. J., \& MacDonald, M. C. (2009). Experience and sentence processing: Statistical learning and relative clause comprehension. Cognitive Psychology, 58, 250-271. 


\section{APPENDIX}

\section{List of all 64 experimental RCs and the English OR translations. Order: Italian/German/English}

Ecco la donna che saluta la ragazza./Hier ist die Frau, die das Mädchen grüßt./Here is the woman that the girl greets.

Ecco la cantante che saluta il ragazzino./Hier ist die Sängerin, die das Kind grüßt./Here is the singer that the Child greets.

Ecco la regina che colpisce la nonna./Hier ist die Königin, die die Großmutter schlägt./Here is the queen that the grandmother hits.

Ecco la pittrice che colpisce la strega./Hier ist die Malerin, die die Hexe schlägt./Here is the painter that the witch hits.

Ecco la tennista che insulta la cameriera./Hier ist die Tennisspielerin, die die Kellnerin beschimpft./Here is the tennis player that the waitress insults.

Ecco la suora che insulta la violinista./Hier ist die Nonne, die die Violinistin beschimpft./Here is the nun that the violinist insults.

Ecco la ballerina che spaventa la fotografa./Hier ist die Ballerina, die die Fotografin erschreckt./ Here is the ballerina that the photographer scares.

Ecco la nonna che spaventa la pittrice./Hier ist die Großmutter, die die Malerin erschreckt./Here is the grandmother that the painter scares.

Ecco la dottoressa che insegue la tennista./Hier ist die Doktorin, die die Tennisspielerin verfolgt./ Here is the doctor that the tennis player chases.

Ecco la cameriera che insegue l'infermiera./Hier ist die Kellnerin, die die Krankenschwester verfolgt./Here is the waitress that the singer kisses.

Ecco la ragazza che bacia la cantante./Hier ist das Mädchen, das die Sängerin küsst./Here is the girl that the singer kisses.

Ecco la violinista che bacia la donna./Hier ist die Violinistin, die die Frau küsst./Here is the violinist that the woman kisses

Ecco il ragazzino che spinge la regina./Hier ist das Kind, das die Königin schubst./Here is the child that the queen pushes

Ecco la fotografa che spinge la dottoressa./Hier ist die Fotografin, die die Doktorin schubst./ Here is the photographer that the doctor pushes.

Ecco l'infermiera che abbraccia la ballerina./Hier ist die Krankenschwester, die die Ballerina umarmt./Here is the nurse that the ballerina hugs.

Ecco la strega che abbraccia la suora./Hier ist die Hexe, die die Nonne umarmt./Here is the witch that the nun hugs.

Ecco la ragazza che pizzica la donna./Hier ist das Mädchen, das die Frau kneift./Here is the girl that the woman pinches.

Ecco il ragazzino che pizzica la cantante./Hier ist das Kind, das die Sängerin kneift./Here is the child that the singer pinches.

Ecco l'infermiera che chiama la cameriera./Hier ist die Krankenschwester, die die Kellnerin ruft./ Here is the nurse that the waitress calls.

Ecco la tennista che chiama la dottoressa./Hier ist die Tennisspielerin, die die Doktorin ruft./ Here is the tennis player that the doctor calls.

Ecco la regina che pettina il ragazzino./Hier ist die Königin, die das Kind kämmt./Here is the queen that the child combs.

Ecco la dottoressa che pettina la fotografa./Hier ist die Doktorin, die die Fotografin kämmt./ Here is the doctor that the photographer combs.

Ecco la nonna che strangola la regina./Hier ist die Großmutter, die die Königin stranguliert./ 
Here is the grandmother that the queen strangles.

Ecco la strega che strangola la pittrice./Hier ist die Hexe, die die Malerin stranguliert./Here is the witch that the painter strangles.

Ecco la cantante che spruzza la ragazza./Hier ist die Sängerin, die das Mädchen bespritzt./Here is the singer that the girl splashes.

Ecco la donna che spruzza la violinista./Hier ist die Frau, die die Violinistin bespritzt./Here is the woman that the violinist splashes.

Ecco la suora che minaccia la strega./Hier ist die Nonne, die die Hexe bedroht./Here is the nun that the witch threatens.

Ecco la ballerina che minaccia l'infermiera./Hier ist die Ballerina, die die Krankenschwester bedroht./Here is the ballerina that the nurse threatens.

Ecco la fotografa che sveglia la ballerina./Hier ist die Fotografin, die die Ballerina weckt./Here is the photographer that the ballerina wakes.

Ecco la pittrice che sveglia la nonna./Hier ist die Malerin, die die Großmutter weckt./Here is the painter that the grandmother wakes.

Ecco la cameriera che gratta la tennista./Hier ist die Kellnerin, die die Tennisspielerin kratzt./ Here is the waitress that the tennis player scratches.

Ecco la violinista che gratta la suora./Hier ist die Violinistin, die die Nonne kratzt./Here is the violinist that the nun scratches.

Ecco la ragazza che insulta la donna./Hier ist das Mädchen, das die Frau beschimpft./Here is the girl that the woman insults.

Ecco il ragazzino che insulta la cantante./Hier ist das Kind, das die Sängerin beschimpft./Here is the child that the singer insults.

Ecco la nonna che bacia la regina./Hier ist die Großmutter, die die Königin küsst./Here is the grandmother that the queen kisses.

Ecco la strega che bacia la pittrice./Hier ist die Hexe, die die Malerin küsst./Here is the witch that the painter kisses.

Ecco la cameriera che sveglia la tennista./Hier ist die Kellnerin, die die Tennisspielerin weckt./ Here is the waitress that the tennis player wakes.

Ecco la violinista che sveglia la suora./Hier ist die Violinistin, die die Nonne weckt./Here is the violinist that the nun wakes.

Ecco la fotografa che chiama la ballerina./Hier ist die Fotografin, die die Ballerina ruft./Here is the photographer that the ballerina calls.

Ecco la pittrice che chiama la nonna./Hier ist die Malerin, die die Großmutter ruft./Here is the painter that the grandmother calls.

Ecco l'infermiera che spaventa la cameriera./Hier ist die Krankenschwester, die die Kellnerin erschreckt./Here is the nurse that the waitress scares.

Ecco la tennista che spaventa la dottoressa./Hier ist die Tennisspielerin, die die Doktorin erschreckt./Here is the tennis player that the doctor scares.

Ecco la cantante che insegue la ragazza./Hier ist die Sängerin, die das Mädchen verfolgt./Here is the singer that the girl chases.

Ecco la donna che insegue la violinista./Hier ist die Frau, die die Violinistin verfolgt./Here is the woman that the violinist chases.

Ecco la regina che minaccia il ragazzino./Hier ist die Königin, die das Kind bedroht./Here is the queen that the child threatens.

Ecco la dottoressa che minaccia la fotografa./Hier ist die Doktorin, die die Fotografin bedroht./ Here is the doctor that the photographer threatens.

Ecco la suora che saluta la strega./Hier ist die Nonne, die die Hexe grüßt./Here is the nun that the witch greets.

Ecco la ballerina che saluta l'infermiera./Hier ist die Ballerina, die die Krankenschwester grüßt./ 
Here is the ballerina that the nurse greets.

Ecco la cantante che abbraccia il ragazzino./Hier ist die Sängerin, die das Kind umarmt./Here is the singer that the child hugs.

Ecco la donna che abbraccia la ragazza./Hier ist die Frau, die das Mädchen umarmt./Here is the woman that the girl hugs.

Ecco la dottoressa che strangola la tennista./Hier ist die Doktorin, die die Tennisspielerin stranguliert./Here is the doctor that the tennis player strangles.

Ecco la cameriera che strangola l'infermiera./Hier ist die Kellnerin, die die Krankenschwester stranguliert./Here is the waitress that the nurse strangles.

Ecco la fotografa che spruzza la dottoressa./Hier ist die Fotografin, die die Doktorin bespritzt./ Here is the photographer that the doctor splashes.

Ecco il ragazzino che spruzza la regina./Hier ist das Kind, das die Königin bespritzt./Here is the child that the queen splashes.

Ecco la pittrice che pizzica la strega./Hier ist die Malerin, die die Hexe kneift./Here is the painter that the witch pinches.

Ecco la regina che pizzica la nonna./Hier ist die Königin, die die Großmutter kneift./Here is the queen that the grandmother pinches.

Ecco la violinista che colpisce la donna./Hier ist die Violinistin, die die Frau schlägt./Here is the violinist that the woman hits.

Ecco la ragazza che colpisce la cantante./Hier ist das Mädchen, das die Sängerin schlägt./Here is the girl that the singer hits.

Ecco la strega che pettina la suora./Hier ist die Hexe, die die Nonne kämmt./Here is the witch that the nun combs.

Ecco l'infermiera che pettina la ballerina./Hier ist die Krankenschwester, die die Ballerina kämmt./Here is the nurse that the ballerina combs.

Ecco la nonna che gratta la pittrice./Hier ist die Großmutter, die die Malerin kratzt./Here is the grandmother that the painter scratches.

Ecco la ballerina che gratta la fotografa./Hier ist die Ballerina, die die Fotografin kratzt./Here is the ballerina that the photographer scratches.

Ecco la suora che spinge la violinista./Hier ist die Nonne, die die Violinistin schubst./Here is the nun that the violinist pushes.

Ecco la tennista che spinge la cameriera./Hier ist die Tennisspielerin, die die Kellnerin schubst./ Here is the tennis player that the waitress pushes. 